\title{
TPD52 wt Allele
}

National Cancer Institute

\section{Source}

National Cancer Institute. TPD52 wt Allele. NCI Thesaurus. Code C52140.

Human TPD52 wild-type allele is located in the vicinity of $8 q 21$ and is approximately 137 $\mathrm{kb}$ in length. This allele, which encodes tumor protein D52, may be involved in calciummediated signaling and mitotic progression. The wild-type allele is aberrantly expressed in several cancers. 